\title{
Perilaku Cuci Tangan Sebelum Makan dan Kecacingan pada Murid SD di Kabupaten Pesisir Selatan Sumatera Barat
}

\author{
Zaidina Umar*
}

\begin{abstract}
Abstrak
Di Indonesia penyakit cacingan tersebar luas di pedesaan dan di perkotaan dengan prevalensi semua umur 40\%-60\% dan murid SD 60-80\%. Survei Depkes RI di 10 propinsi di Indonesia menemukan prevalensi kecacingan di Kabupaten Pesisir Selatan tahun 2003 (85, 8\%) dan tahun 2005 (51,4\%) lebih tinggi dari kabupaten lain. Angka infeksi kecacingan tinggi dipengaruhi oleh kebersihan diri, sanitasi lingkungan dan kebiasaan penduduk. Tujuan penelitian untuk mengetahui hubungan perilaku cuci tangan dengan kejadian kecacingan pada murid SD Kabupaten Pesisir Selatan. Penelitian dengan desain cross sectional ini menggunakan data sekunder hasil survei kecacingan Depkes RI tahun 2005, jumlah sampel 257 orang. Diagnosis penyakit kecacingan ditegakkan berdasarkan pemeriksaan telur cacing pada tinja dengan metode Katto-Katz. Hasil penelitian menunjukan perilaku cuci tangan memakai air dan sabun sebelum makan terbukti berhubungan bermakna dengan kejadian kecacingan ( $\mathrm{OR}=2,35,95 \% \mathrm{Cl}=1,40-3,94)$, variabel lain yang berhubungan bermakna adalah perilaku $\mathrm{BAB}$ tidak dijamban dengan nilai $\mathrm{OR}=2,64(95 \% \mathrm{Cl}=1,46-4,77)$ dan perilaku jajan bukan di warung sekolah $(\mathrm{OR}=1,96(95 \% \mathrm{Cl}=1,06-3,65)$. Murid SD dan masyarakat disarankan mencuci tangan sebelum makan dengan air dan sabun. Di samping pengobatan, perlu dilakukan penyuluhan kesehatan dan peningkatan PHBS pada murid dengan pemeriksaan berkala perilaku dan kebersihan diri di sekolah.
\end{abstract}

Kata kunci : Cuci tangan, kecacingan, kebersihan diri, sanitasi lingkungan

\begin{abstract}
In Indonesia, helminth infection spread out at rural and urban community with prevalence at elementary school of $60 \%$ - $80 \%$ and for all age of $40 \%-60 \%$. Helminths prevalence in Pesisir Selatan district is higher than that of other districts which was $85,8 \%$ on 2003 and 51,4 on 2005 . Helmints infection depends on personal hygiene, environmental sanitation and residential habit. The objective of the this study is to know relationship between hand washing behaviour before eating with helminths occurrence among elementary school students in Pesisir Selatan. This research uses cross sectional design, using secondary data of helminths survey of Ministry of Health RI on 2005, with total sample of 257 students. Helminths disease diagnosis was based on laboratory examination of helminth eggs in human feces using Katto-Katz methods. Research's results showing that hand washing behaviour before eating is related to helminths occurrence $(\mathrm{OR}=2,35,95 \% \mathrm{Cl}=1,40-3,94)$, other variables with statistically significant relationship to helminths occurrence is defecation behavior not at the toilet $(\mathrm{OR}=2,64 ;(95 \% \mathrm{ClOR}=1,46-4,77)$ and eating snacks in small shop at school $(\mathrm{OR}=1,96 ; 95 \% \mathrm{Cl}=1,06-3,65)$. It is recommended to elementary school student and society to familiarize to hand washing before eating with water and soap. In order to prevent and eradicate helminths disease, beside curative effort, there is a need to do health counseling about healthy and clean living (PHBS), undertaking periodical evaluation on behaviour and personal hygiene of student at school
\end{abstract}

Key words : Hand washing, helminths, personal hygiene, environmental sanitation

*Petugas Surveilans Epidemiologi Dinas Kesehatan Kabupaten Pesisir Selatan, Jl. H. Agus Salim Painan Kabupaten Pesisir Selatan Sumatera Barat 25611 (e-mail : zaidinaumar@yahoo.com) 
Penyakit infeksi parasit cacing masih menjadi masalah kesehatan masyarakat yang penting, terutama di negara berkembang atau negara miskin di seluruh dunia. Diperkirakan lebih dari 2 milyar orang terinfeksi cacing di seluruh dunia, sekitar 300 juta menderita infeksi cacing yang berat dan sekitar 150.000 kematian terjadi setiap tahun akibat infeksi $S T H$. Laporan terakhir memperkirakan infeksi A. lumbricoides sebesar 1,2 milyar, T. trichiura 795 juta dan cacing tambang 740 juta. 1,2 Penyakit cacingan menimbulkan dampak yang besar pada masyarakat karena mempengaruhi pemasukan (intake), pencernaan (digestif), penyerapan (absorbsi) dan metabolisme makanan. Secara kumulatif infeksi cacing dapat menimbulkan kerugian zat gizi berupa kalori dan protein serta kehilangan darah, menghambat perkembangan fisik, mental, kemunduran intelektual pada anak-anak dan produktifitas kerja, dapat menurunkan ketahanan tubuh sehingga mudah terkena penyakit lainnya. ${ }^{3}$

Di Indonesia penyakit cacingan tersebar luas di pedesaan maupun di perkotaan. Hasil survei infeksi kecacingan di sekolah dasar (SD) di beberapa propinsi menunjukan prevalensi sekitar $60 \%-80 \%$, sedangkan untuk semua umur berkisar antara $40 \%-60 \% .{ }^{4}$ Hasil survei pada tahun 2002 dan 2003 pada 40 sekolah dasar pada 10 propinsi di Indonesia menunjukan prevalensi berkisar antara 2,2\% - 96,3\%.3 Dari hasil survei prevalensi yang dilakukan pada 10 propinsi di Indonesia sejak tahun 2002 s/d 2005, prevalensi kecacingan pada murid SD di Kabupaten Pesisir Selatan cukup tinggi dibanding kabupaten lain. Tahun 2003 prevalensi kecacingan paling tinggi yaitu 85,77\%. Tahun 2005 prevalensi kecacingannya urutan kedua tertinggi setelah Lombok Timur yaitu 51,36\%. Survei kecacingan pada murid SD di Kabupaten Pesisir Selatan tahun 2004 mendapatkan perilaku murid SD yang mencuci tangan sebelum makan (92\%), tetapi perilaku murid mencuci tangan sebelum makan dengan air dan sabun hanya $47 \%$. Tujuan penelitian ini untuk mengetahui hubungan perilaku cuci tangan sebelum makan memakai air dan sabun dengan kejadian kecacingan (A.lumbricoides dan T.trichiura) pada murid kelas 3 - 5 SD 28 dan 34 Kecamatan Bayang dan SD 19 \& 22 Kecamatan IV Jurai Kabupaten Pesisir Selatan.

\section{Metode}

Penelitian ini merupakan studi epidemiologi dengan desain cross sectional yang dilakukan terhadap data sekunder hasil survei kecacingan oleh Ditjen PPM \& PL Depkes RI tahun 2005 di Kabupaten Pesisir Selatan. Sampel penelitian diambil dari seluruh sampel survei kecacingan Depkes RI tahun 2005 di Kabupaten Pesisir Selatan yaitu murid kelas 3 - 5 SD 28 dan 34 Kecamatan Bayang dan SD 19 dan 22 Kecamatan IV Jurai dengan total sampel 257 orang. Pengumpulan data dilakukan pada bulan Maret 2007. Besar sampel minimal dihitung berdasarkan rumus penentuan besar sampel untuk uji hipotesis odds ratio seperti yang terdapat dalam buku "Adequacy of Sample Size in Health Studies". ${ }^{5}$ Cara pengambilan sampel sesuai dengan metode pengambilan sampel survei kecacingan Depkes RI di Kabupaten Pesisir Selatan tahun 2005. Pada saat pelaksanaan survei sampel tidak dipilih secara random dari populasi target, tetapi dipilih berdasarkan kriteria tertentu (purposif). Pemilihan sasaran lokasi (propinsi dan kabupaten) antara lain meliputi daerah pertanian, perkebunan, daerah pantai dan pariwisata. Kabupaten Pesisir Selatan Propinsi Sumatera Barat (Sumbar) terpilih salah satu dari 10 lokasi yang ditetapkan Depkes RI. Selanjutnya dipilih 2 kecamatan dari 11 kecamatan yang ada di Kabupaten Pesisir Selatan yaitu kecamatan yang punya puskesmas dengan sarana dan sumber daya yang lebih baik. Pada setiap kecamatan dipilih 2 SD dengan kriteria 1 SD dekat pantai dan 1 SD tidak dekat pantai. Selanjutnya dipilih semua murid kelas 3 - 5 pada setiap SD.

Pada penelitian ini analisis bivariat digunakan untuk menyeleksi variabel independen kandidat model menggunakan uji kai kuadrat (Chi Square). Kriteria kandidat model multivariat adalan nilai $\mathrm{p} \geq 0,25$. Ukuran asosiasi yang digunakan adalah Prevalence Odds Ratio (POR), yaitu membandingkan prevalence odds terkena penyakit pada kelompok terpajan dengan prevalence odds terkena penyakit pada kelompok tidak terpajan. ${ }^{6}$ Analisis multivariat dilakukan untuk melihat hubungan variabel independen utama dengan variabel dependen setelah faktor-faktor lain dikendalikan, analisis yang digunakan adalah uji regresi logistik ganda model faktor risiko.

\section{Hasil}

Penelitian ini menemukan kejadian kecacingan positif sebesar 51,4\% dan kejadian kecacingan negatif sebesar 48,6\%. (Lihat Tabel 1)

\section{Analisis Bivariat}

Semua variabel independen yang diamati meliputi cuci tangan sebelum makan dengan air dan sabun, perilaku BAB (buang air besar), sarana air bersih, perilaku cuci tangan setelah $\mathrm{BAB}$, cuci tangan setelah $\mathrm{BAB}$ dengan air dan sabun, pengetahuan tentang penyakit cacingan, perilaku jajan di sekolah dan kebersihan kuku memenuhi kriteria kandidat model multivariat (nilai $\mathrm{p} \leq$ 0,25). (Lihat Tabel 2)

Dari model multivariat terlihat bahwa cuci tangan sebelum makan memakai air dan sabun (nilai $\mathrm{p}=0,015$, $\mathrm{OR}=2,16 ; 95 \% \mathrm{CI}$ OR $=1,16-4,02$ ); perilaku buang air besar (nilai $\mathrm{p}=0,008$, OR $=2,33$; 95\% CI OR $=1,24$ 4,37 ) dan perilaku jajan di sekolah (nilai $\mathrm{p}=0,035$, OR 
Tabel 1. Distribusi Kecacingan Munurut Kecamatan D Kabupaten Pesisir Selatan

\begin{tabular}{|c|c|c|c|c|c|c|}
\hline \multirow{3}{*}{$\begin{array}{l}\text { Kejadian } \\
\text { Kecacingan }\end{array}$} & \multicolumn{4}{|c|}{ Kecamatan } & & \\
\hline & \multicolumn{2}{|c|}{ Bayang } & \multicolumn{2}{|c|}{ IV Jurai } & \multicolumn{2}{|c|}{ Total } \\
\hline & Jml & $\%$ & Jml & $\%$ & Jml & $\%$ \\
\hline Positif & 73 & 63 & 59 & 42 & 132 & 51,4 \\
\hline Negatif & 43 & 37 & 82 & 58 & 125 & 48,6 \\
\hline Total & 116 & 100 & 141 & 100 & 257 & 100 \\
\hline
\end{tabular}

Tabel 2. Hasil Analisis Bivariat Faktor Risiko Kecacingan pada Murid SD Kabupaten Pesisir Selatan

\begin{tabular}{|c|c|c|}
\hline Faktor Risiko & Katagori & Nilai $p$ \\
\hline $\begin{array}{l}\text { Cuci tangan sebelum makan dengan air } \\
\text { dan sabun }\end{array}$ & $\begin{array}{l}\text { Tidak ada } \\
\text { Ada }\end{array}$ & $0,002 *$ \\
\hline Perilaku BAB & $\begin{array}{l}\text { Tdk di jamban } \\
\text { Di jamban }\end{array}$ & $0,001 *$ \\
\hline Sarana air bersih & $\begin{array}{l}\text { Tdk memenuhi Syarat } \\
\text { Memenuhi Syarat }\end{array}$ & $0,042 *$ \\
\hline Perilaku cuci tangan setelah BAB & $\begin{array}{l}\text { Tidak ada } \\
\text { Ada }\end{array}$ & $0,026^{*}$ \\
\hline Cuci tangan setelah BAB dg air dan sabun & $\begin{array}{l}\text { Tidak ada } \\
\text { Ada }\end{array}$ & $0,038^{*}$ \\
\hline Pengetahuan tentang penyakit cacingan & $\begin{array}{l}\text { Kurang } \\
\text { Cukup }\end{array}$ & 0,079 \\
\hline Perilaku jajan di sekolah & $\begin{array}{l}\text { Tdk di warung sekolah } \\
\text { Di warung sekolah }\end{array}$ & $0.001 *$ \\
\hline Kebersihan kuku & $\begin{array}{l}\text { Kotor } \\
\text { Bersih }\end{array}$ & $0,171^{*}$ \\
\hline
\end{tabular}

$=2,01,95 \%$ CI OR $=1,05-3,86$ ) berpengaruh secara statistik bermakna terhadap kecacingan. (Lihat Tabel 3)

Hasil uji interaksi tidak menemukan variabel interaksi sehingga model awal tersebut dijadikan pertimbangan untuk menentukan variabel-variabel independen yang berpengaruh. Langkah selanjutnya adalah melakukan uji confounding. Penilaian confounding pada analisa multivariat regresi logistik dilakukan terhadap variabel kovariat yang terpilih sebagai kandidat model. Pada penelitian ini penilaian confounder dengan membandingkan nilai OR variabel utama antara sebelum dan sesudah variabel kandidat confounder dikeluarkan. Apabila perbedaan nilai OR untuk variabel utama dengan dikeluarkannya variabel kandidat confounding $>10 \%$, maka variabel tersebut dianggap sebagai variabel confounding. Berdasarkan hasil analisis penilaian confounding didapatkan bahwa semua variabel kovariat bukan merupakan variabel confounder pada hubungan perilaku cuci tangan sebelum makan memakai air dan sabun dengan kejadian kecacingan (index confounding $<10 \%$ ).

\section{Pembahasan \\ Perilaku Cuci Tangan}

Kebiasaan cuci tangan sebelum makan memakai air dan sabun mempunyai peranan penting dalam kaitannya dengan pencegahan infeksi kecacingan, karena dengan mencuci tangan dengan air dan sabun dapat lebih efektif menghilangkan kotoran, debu dan telur cacing yang menempel pada permukaan kulit dan kuku pada kedua tangan. Dengan demikian perilaku cuci tangan sebelum makan memakai air dan sabun berpengaruh terhadap kejadian infeksi kecacingan. Pada penelitian ini, berdasarkan hasil analisis bivariat seperti terlihat pada tabel 3 terlihat bahwa responden yang tidak cuci tangan sebelum makan memakai air dan sabun pada kelompok kecacingan positif sebesar 47,7 \% dan lebih rendah padakelompok kecacingan negatif yaitu sebesar $28,0 \%$. Hasil uji bivariat hubungan perilaku cuci tangan sebelum makan memakai air dan sabun dengan kejadian kecacingan secara statistik terbukti signifikan (nilai $p=0,002$ ) dengan OR $=2,35$ (95\% CI: 1,40-3,94).

Dari hasil pemodelan lengkap menunjukan bahwa variabel perilaku cuci tangan sebelum makan memakai air dan sabun, perilaku buang air besar dan perilaku jajan di sekolah berhubungan secara signifikan dengan kejadian kecacingan (nilai $\mathrm{p}<0,05$ ). Hasil penilaian interaksi antara variabel independen utama dengan semua variabel kandidat interaksi, ternyata tidak ada satupun variabel interaksi ditemukan, maka model selanjutnya dengan tidak mengikutsertakan variabel interaksi. Hasil penilaian confounding terhadap variabel kandidat yang terpilih dalam model, yaitu variabel perilaku cuci tangan sebelum makan memakai air dan sabun dengan variabel kandidat confounder yaitu variabel perilaku $\mathrm{BAB}$, sarana air bersih, perilaku cuci tangan setelah $\mathrm{BAB}$, perilaku cuci tangan setelah $\mathrm{BAB}$ dengan air dan sabun, pengetahuan tentang penyakit cacing, perilaku jajan di sekolah dan kebersihan kuku. Penilaian dilakukan dengan cara membandingkan nilai OR sebelum dan sesudah variabel kandidat confounder dikeluarkan. Dari hasil penilaian confounding ternyata ditemukan bahwa semua variabel kovariat bukan merupakan confounder dalam melihat hubungan perilaku cuci tangan sebelum makan memakai air dan sabun dengan kejadian kecacingan. Karena setelah variabel kovariat masing-masingnya dikeluarkan satu persatu dari model perbedaan $\mathrm{OR}_{\text {full model }}$ dan $\mathrm{OR}_{\text {reduced model }}$ tidak lebih dari $10 \%$. Sehingga dapat dikatakan bahwa variabel perilaku BAB, sarana air bersih, perilaku cuci tangan setelah $\mathrm{BAB}$, perilaku cuci tangan setelah $\mathrm{BAB}$ dengan air dan sabun, pengetahuan tentang penyakit cacing, perilaku jajan di sekolah dan kebersihan kuku bukan variabel confounder.

Hasil penelitian ini juga sejalan dengan beberapa penelitian sebelumnya. Pada penelitian Nurlila, ${ }^{7}$ di SDN 23 dan 24 Rawa Badak Utara Jakarta Utara diperoleh nilai $\mathrm{OR}_{\text {crude }}=9,21(95 \% \mathrm{CI}=4,82-17,58)$. Pada penelitian Olsen, et.al, ${ }^{8}$ di Kisumu District Kenya didapatkan hubungan yang signifikan antara keluarga yang melakukan kebiasaan cuci tangan tidak pakai sabun 
Tabel 3. Model Multivariat Perilaku Cuci Tangan dan Kecacingan pada Murid SD di Kabupaten Pessisir Selatan

\begin{tabular}{|c|c|c|c|c|}
\hline Variabel Independen & B & p Wald & OR & $95 \% \mathrm{CI}$ \\
\hline Cuci Tangan Sebelum Makan Memakai Air \& Sabun & 0,772 & $0,015^{*}$ & 2,16 & $1,16-4,02$ \\
\hline Perilaku Buang Air Besar & 0,847 & $0,008^{*}$ & 2,33 & $1,24-4,37$ \\
\hline Sarana Air Bersih & 0,506 & 0,076 & 1,66 & $0,95-2,90$ \\
\hline Cuci Tangan Setelah BAB & 0,509 & 0,269 & 1,66 & $0,68-4,10$ \\
\hline Cuci Tangan Setelah BAB Dengan Air \& Sabun & $-0,054$ & 0,871 & 0,95 & $0,49-1,82$ \\
\hline Pengetahuan Tentang Penyakit Cacing & 1,009 & 0,069 & 2,74 & $0,92-8,16$ \\
\hline Perilaku Jajan di Sekolah & 0,699 & $0.035^{*}$ & 2,01 & $1,05-3,86$ \\
\hline Kebersihan Kuku & $-0,547$ & 0,089 & 0,58 & $0,31-1,09$ \\
\hline
\end{tabular}

Keterangan : * nilai $\mathrm{p}<0,05$ atau signifikan

berisiko 2,6 kali lebih besar terinfeksi Ascaris lumbricoides dibandingkan dengan keluarga yang melakukan kebiasaan cuci tangan pakai sabun. Sedangkan penelitian Mahfudin dkk, ${ }^{9}$ di SDN 01 dan 06 Duren Sawit Jakarta Timur, didapatkan perbedaan angka reinfeksi yang sangat bermakna antara siswa SD yang melakukan kebiasaan cuci tangan dengan sabun sebelum makan $(1,68 \%)$ dengan yang tidak cuci tangan sebelum makan $(7,25 \%)$ setelah 3 bulan pengobatan. Menurut Mahfudin dkk, transmisi Ascaris lumbricoides selain dikurangi dengan menghilangkan sumber infeksi, juga dapat dihilangkan dengan menggalakkan cuci tangan dengan sabun sebelum makan. Penelitian ini juga sejalan dengan yang dikemukakan Margono, at al., dalam Nurlila, ${ }^{7}$ bahwa perilaku cuci tangan dengan air dan sabun sebelum makan berpengaruh terhadap transmisi Ascaris lumbricoides dan Trichuris trichiura.

Dapat dijelaskan bahwa cuci tangan sebelum makan dengan air dan sabun merupakan cara efektif untuk mencegah penularan berbagai penyakit, salah satunya infeksi kecacingan. Tujuan cuci tangan adalah menghilangkan kotoran dan debu secara mekanis dari permukaan kulit dan secara bermakna mengurangi jumlah mikroorganisme penyebab penyakit seperti virus, bakteri dan parasit lainnya pada kedua tangan. Mencuci tangan dengan menggunakan air dan sabun dapat lebih efektif membersihkan kotoran dan telur cacing yang menempel pada permukaan kulit, kuku dan jari-jari kedua belah tangan, karena menurut Tietjen, ${ }^{10}$ sabun dan deterjen dapat menurunkan tegangan permukaan sehingga lebih efektif membantu membuang kotoran, debu dan mikroorganisme dari kedua belah tangan. Terbuktinya hubungan perilaku cuci tangan sebelum makan memakai air dan sabun dengan kejadian kecacingan hal ini dapat diasumsikan bahwa perilaku cuci tangan sebelum makan memakai air dan sabun merupakan kegiatan penting yang berkaitan langsung dengan upaya mencegah masuknya telur cacing kedalam tubuh melalui tangan, sehingga menjadi faktor penting yang berkaitan langsung dengan pencegahan infeksi kecacingan.

\section{Faktor Risiko Lain}

\section{Perilaku buang air besar (BAB)}

Pada penelitian ini perilaku buang air besar terlihat tetap signifikan (nilai $\mathrm{p}<0,05$ ) pada hasil uji statistik baik bivariat maupun analisa multivariat regresi logistik ganda. Secara statistik variabel perilaku buang air besar tidak terjadi interaksi dengan variabel utama secara signifikan dan tidak sebagai variabel confounder pada hubungan perilaku cuci tangan sebelum makan memakai air dan sabun dengan kejadian kecacingan. Pada model akhir analisis multivariat regresi logistik variabel perilaku $\mathrm{BAB}$ didapatkan nilai $\mathrm{OR}=2,64(95 \% \mathrm{CI}: 1,46-4,77)$. Beberapa penelitian lain juga memberikan hasil yang sejalan dengan penelitian ini, seperti penelitian Quihui at.al, ${ }^{11}$ pada anak sekolah di Sinaloa dan Oaxaca Mexico bahwa anak yang $\mathrm{BAB}$ di area terbuka kemungkinan berisiko terinfeksi kecacingan 2,4 kali lebih besar dibanding anak yang BAB di jamban. Menurut Puslit Ekologi Kesehatan, Balitbangkes Depkes RI, di daerah yang punya jamban prevalensi A. lumbricoides jauh lebih rendah $(12,1 \%)$ dibandingkan dengan daerah yang tidak punya jamban $(22,8 \%)$, sedangkan untuk $T$. trichiura tidak ada perbedaan prevalensi $(2,8 \%$ dan 3,6\%).

Dapat dipahami bahwa anak yang BAB tidak di jamban atau $\mathrm{BAB}$ di sembarang tempat menyebabkan pencemaran tanah dan lingkungan oleh tinja yang berisi telur cacing. Penyebaran infeksi kecacingan tergantung dari lingkungan yang tercemar tinja yang mengandung telur cacing. Infeksi pada anak sering terjadi karena menelan tanah yang tercemar telur cacing atau melalui tangan yang terkontamisasi telur cacing. Penularan melalui air sungai juga dapat terjadi, karena air sungai sering digunakan untuk berbagai keperluan dan aktifitas seperti mandi, cuci dan tempat buang air besar.

\section{Sarana Air Bersih (SAB)}

Analisis multivariat tidak menunjukan hubungan yang signifikan (nilai $\mathrm{p}=0,076$ ). Menurut Kan, et al., dalam Refirman, ${ }^{12}$ bahwa prevalensi A. lumbricoides dan T. trichiura tertinggi terdapat pada keluarga dengan suplai air 
tanpa pipa, sedangkan infeksi cacing tambang tidak tergantung dari suplai air. Pada penelitian Refirman, ${ }^{12}$ di SD T. Bungin \& SD. Rengit Kabupaten Musi Banyuasin Sumatera Selatan didapatkan bahwa aspek lingkungan tidak berhubungan dengan prevalensi $S T H$, namun demikian sumber air minum yang berasal dari sumur terbuka lebih banyak ditemukan penderita A. lumbricoides, T. trichiura dan cacing tambang. Hubungan sarana air bersih dengan kejadian kecacingan yang tidak signifikan pada penelitian ini diduga karena SAB yang dikategorikan memenuhi syarat yaitu ledeng, SPT dan sumur pompa listrik belum tentu sudah terbebas dari pencemaran telur cacing. Disamping itu dimungkinkan juga karena jumlah sampelnya kurang memadai karena proporsi jumlah sampel tidak dihitung dari frekuensi sarana air bersih tapi dari proporsi perilaku cuci tangan sebelum makan memakai air dan sabun.

\section{Perilaku Cuci Tangan Setelah BAB}

Analisis multivariat tidak menunjukan hubungan yang signifikan (nilai $p=0,368$ ) yang diduga karena faktor perilaku cuci tangan setelah $\mathrm{BAB}$ bukan faktor risiko yang berhubungan langsung dengan pencegahan infeksi kecacingan. Faktor risiko ini terpengaruh oleh variabel lain seperti perilaku cuci tangan sebelum makan memakai air dan sabun. Walaupun anak sudah cuci tangan sesudah $\mathrm{BAB}$, tetapi tangan anak mungkin saja kotor lagi dan tercemar telur cacing saat bermain di tanah, apabila anak tidak cuci tangan sebelum makan, atau mungkin cuci tangan tapi tidak menggunakan sabun sehingga tidak bersih maka anak tetap berisiko terinfeksi kecacingan.

\section{Cuci Tangan Setelah BAB dengan Air dan Sabun}

Analisis multivariat tidak menunjukan hubungan yang signifikan (nilai $p=0,972$ ). Yang diduga karena perilaku cuci tangan setelah $\mathrm{BAB}$ dengan air dan sabun bukan kegiatan yang berhubungan langsung dengan upaya mencegah masuknya telur cacing ke dalam tubuh melalui tangan atau faktor risiko ini terpengaruh oleh adanya variabel lain seperti perilaku cuci tangan sebelum makan memakai air dan sabun. Selain itu sesuai dengan ketersedian data pada penelitian ini tidak bisa secara jelas diketahui apakah perilaku cuci tangan dengan air dan sabun selalu dilakukan setiap kali setelah BAB atau hanya kadang-kadang sehingga tidak dapat dibuktikan signifikan dalam uji statistik. Hasil penelitian ini belum dapat mendukung yang dikemukakan Depkes RI, ${ }^{3}$ bahwa dalam upaya pencegahan dan pemberantasan kecacingan antara lain dapat dilakukan dengan membiasakan perilaku mencuci tangan sebelum makan dan setiap kali selesai buang air besar dengan menggunakan air dan sabun. ${ }^{3}$

\section{Pengetahuan Tentang Penyakit Cacing}

Hasil uji statistik bivariat menunjukan bahwa hubungan pengetahuan murid tentang penyakit cacing dengan kejadian kecacingan tidak signifikan secara statistik (nilai $\mathrm{p}=0,079$ ), sehingga tidak disertakan dalam model multivariat. Hasil ini tidak sesuai dengan penelitian sebelumnya bahwa dalam upaya pencegahan dan pemberantasan infeksi kecacingan peningkatan pendidikan dan pengetahuan masyarakat sebaiknya tidak dilupakan. Masyarakat akan dapat melindungi dirinya dari penyakit jika mereka tahu agent penyebabnya dan bagaimana cara mencegah penularannya. Langkah promotif diperlukan untuk meningkatkan pengetahuan masyarakat akan pentingnya menjaga kebersihan lingkungan dan hygiene pribadi dengan menghilangkan kebiasaan buruk yang mendukung penularan infeksi kecacingan. Pendidikan dan pengetahuan ikut menentukan perilaku seseorang. ${ }^{13}$

Hubungan yang tidak bermakna tersebut mungkin disebabkan oleh pengetahuan yang tidak akan berpengaruh langsung terhadap kesehatannya, pengaruhnya akan dirasakan bila pengetahuan tersebut dipraktekkan dalam bentuk perilaku sehat pada kehidupan sehari-hari. Disamping itu, sebagian besar murid yaitu sebanyak $92,2 \%$ memiliki pengetahuan rendah tentang penyakit cacing, hal ini menunjukan hasil yang hampir homogen untuk sebuah variabilitas dan dapat menyebabkan terjadinya ketidakmaknaan hubungan. Hal ini diduga karena faktor jumlah sampel yang belum memadai karena proporsi jumlah sampel tidak dihitung dari frekuensi pengetahuan murid tentang penyakit cacing tapi dari proporsi perilaku cuci tangan sebelum makan memakai air dan sabun.

\section{Perilaku Jajan di Sekolah}

Pada model analisis multivariat regresi logistik variabel perilaku jajan di sekolah didapatkan nilai $\mathrm{p}=0,03$ dengan nilai $\mathrm{OR}=1,96(95 \% \mathrm{CI}: 1,06-3,65)$. Pada penelitian Tadesse, ${ }^{14}$ di Babile town eastern Ethiopia, didapatkan bahwa anak yang jajan makanan di pinggir jalan di sekitar sekolah lebih tinggi prevalensi infeksi A.lumbricoides dan T.trichiura dibanding anak yang tidak jajan di pinggir jalan, tetapi perbedaan ini tidak bermakna secara statistik $(p=0,05)$. Perilaku anak jajan di sembarang tempat yang kebersihannya tidak dapat dikontrol oleh pihak sekolah dan tidak terlindung dan dapat tercemar oleh debu dan kotoran yang mengandung telur cacing, hal ini dapat menjadi sumber penularan infeksi kecacingan pada anak. Selain melalui tangan, transmisi telur cacing dapat juga melalui makanan dan minuman, terutama makanan jajanan yang tidak dikemas dan tidak tertutup rapat. Telur cacing yang ada di tanah/debu akan sampai pada makanan tersebut jika diterbangkan oleh angin atau dapat juga melalui lalat yang sebelumnya hinggap di tanah/selokan sehingga kaki-kakinya membawa telur cacing tersebut, terutama pada jajanan yang tidak tertutup. ${ }^{15}$ 


\section{Kebersihan Kuku}

Pada penelitian ini hasil analisis bivariat tidak memperlihatkan hubungan bermakna sehingga tidak disertakan dalam model multivariat. Hal tersebut diduga karena biasanya pada murid SD dilakukan pemeriksaan kuku setiap minggu, di sekolah anak-anak telah diintervensi dengan pemeriksaan kuku setiap minggu. Hubungan tidak signifikan pada penelitian ini kemungkinan karena pengamatan kebersihan kuku dan kejadian kecacingan dilakukan secara bersamaan atau sekaligus pada saat yang sama dan diukur menurut keadaan atau status waktu diobservasi. Pada metode desain penelitian ini kurang kuat untuk menyimpulkan adanya hubungan faktor risiko dengan efek atau tidak dapat menjelaskan hubungan sebab akibat, karena adanya bias yang disebabkan oleh kemenduan temporal (temporal ambiguity). Hasil penelitian ini belum mendukung hasil penelitian yang dilakukan Pusat Penelitian Ekologi Kesehatan, Badan Penelitian dan Pengembangan Kesehatan Depkes RI bahwa jika anak mempunyai kuku pendek cenderung menunjukan persentase telur cacing sedikit lebih rendah $(2,8 \%)$ daripada anak yang kuku panjang $(4,5 \%)$. Begitu juga dengan keadaan tangan anak balita, bila pada waktu disurvei tangannya kotor maka prevalensi kecacingan akan lebih tinggi $(21,1 \%)$ daripada yang tangannya ber$\operatorname{sih}(13,8 \%)$.

\section{Kesimpulan}

Penelitian ini menemukan : (1) Angka kejadian kecacingan pada murid kelas 3 - 5 SD 28 dan 34 Kecamatan Bayang dan SD 19 dan 22 Kecamatan IV Jurai Kabupaten Pesisir Selatan tahun 2005 adalah $51,4 \%$. Responden yang cuci tangan sebelum makan pakai air dan sabun adalah $61,9 \%$, sebagian besar responden $\mathrm{BAB}$ di jamban $(65 \%)$, responden yang cuci tangan setelah BAB $(86,8 \%)$, pengetahuan tentang penyakit cacing rendah $(92,2 \%)$, perilaku jajan tidak di warung sekolah $(71,8 \%)$, kuku bersih $(66,9 \%)$. (2) Perilaku cuci tangan sebelum makan memakai air dan sabun terbukti berhubungan signifikan dengan kejadian kecacingan. (3) Variabel lain yang terbukti berhubungan kejadian kecacingan adalah perilaku buang air besar dan perilaku jajan di sekolah.

\section{Saran}

Berdasarkan temuan penelitian disarankan : (1) Murid-murid SD dan masyarakat membiasakan diri cuci tangan sebelum makan dengan air dan sabun. (2) Perlu untuk melakukan penyuluhan kesehatan kepada masyarakat tentang peningkatan perilaku hidup bersih dan sehat (PHBS). (3) Pihak sekolah meningkatkan PHBS kepada anak, dengan melakukan pemeriksaan perilaku cuci tangan sebelum makan, perilaku jajan di sekolah, perilaku BAB di jamban, serta penyuluhan kepada murid pengetahuan tentang penyakit cacing dan bahaya kecacingan. (4) Perlu dilakukan penelitian lebih lanjut dengan desain penelitian kohort dengan menyertakan variabel status sosial ekonomi orangtua murid dan faktor lingkungan.

\section{Daftar Pustaka}

1. De Silva NR, Brooker S, Hotez P, Montresor A, Engels D and Savioli L (2003). Soil-Transmitted Helminth Infections : Updating The Global Pisture, Trends in Parasitology, Vol.19; No.12, Desember 2003 : 547551.

2. Suriptiastuti (2006). Infeksi Soil-Transmitted Helminth : Ascariasis, Trichiuriasis dan Cacing Tambang, Bagian Parasitologi FK Universitas Trisakti, Universa Medicina, Vol.25, No.2, April-Juni 2006 ; 84-93.

3. Departemen Kesehatan RI. (2004). Pedoman Umum Program Nasional Pemberantasan Cacingan di Era Desentralisasi, Subdit Diare dan Penyakit Pencernaan Ditjen PPM \& PLP Depkes RI, Jakarta.

4. Departemen Kesehatan RI. (2005). Laporan Hasil Survei Morbiditas Cacingan Tahun 2005, Subdit Diare dan Penyakit Pencernaan Ditjen PPM \& PLP Depkes RI. Jakarta.

5. Lemeshow, S, et.al, (1997). Besar Sampel Dalam Penelitian Kesehatan. Gadjah Mada University Press, Yogyakarta.

6. Zheng, Tangzhang (1998). Principles of Epidemiology, Yale University School of Public Health, Spring 1998 ; 178-193

7. Nurlila(2002). Faktor-Faktor yang Mempengaruhi Infeksi Kecacingan Murid SDN Rawa Badak Utara 23 dan 24 Jakarta Utara Tahun 2002, Tesis Program Pascasarjana IKM Univesitas Indonesia, Depok

8. Olsen, at al. (2001). A Study of Risk Factors for Intestinal Helminth Infections Using Epidemiological and Anthropological Approaches. Journal of Biosocial Science (2001);33: 569-584, Cambridge University Pres,diakses16Mei2007;http://www.journal.cambridge.org/action/displayabstract.

9. Mahfudin, H, dkk., (1994). Pengaruh cuci tangan terhadap reinfeksi Ascaris lumbricoides. Majalah Parasitologi Indonesia, 7 (2): 1-5.

10. Tietjen, Linda at.al. (2004). Panduan Pencegahan Infeksi untuk Fasilitas Pelayanan Kesehatan dengan Sumber Daya Terbatas. Edisi 1. Penerjemah: Saifudin A.B dkk. Yayasan Bina Pustaka Sarwono Prawirohardjo, Jakarta.

11. Quihui, at.al., (2000). Role of the Employment Status and Education of Mother in the Prevalen of Intestinal Parasit Infections in Mexican Rural Schoolchildren. BMC Public Health 2006, Universidad Autonoma de Sinaloa, Mexico, diakses $16 \quad$ Mei,2007; http://www.biomedcentral.com/content/pdf/1471-2458-6-225.pdf.

12. Refirman DJ, (1998). Faktor Pendukung Transmisi STH pada Murid SD di 2 Dusun Kabupaten Musi Banyuasin Propinsi Sumatera Selatan. Tesis Program Pascasarjana Bidang Ilmu Kesehatan Program Studi Ilmu Biomedik Kekhususan Parasitologi Univesitas Indonesia, Jakarta.

13. Muennoo, Chatree, et.al., (1997). The Impact of Primary Health Care Intervention on Reinfection of Soil-Transmitted Helminths. in The Community, the South-East Asian Journal of Tropical Medical and Public Health. Vol. 28, No.4, Des. 1997: 816-819. 